\title{
Editorial
}

\section{Is CSR Rewriting Development?}

\author{
WENDY HARCOURT
}

This issue of Development tackles the issue of Corporate Social Responsibility (CSR) fully aware of the polarization the topic brings to readers of the journal. For some, the engagement of the state and the UN with corporations is the logical outcome of three decades of restructuring of international and national laws to facilitate international trade and investment flows. The stream of conferences, guidelines, frameworks, agreements being made since 1999 are pouring time, resources and money into CSR that secure the rights of corporations and investors to the detriment of people and the environment. ${ }^{1}$ To others, the negotiations and compacts made with business by the State and the UN signal a realistic adjustment to newly emerging forms of global governance that now must rely on private actors (business, NGOs) rather than states. CSR policy and programmes are therefore reasonable, indeed necessary, steps to secure responsible corporate behaviour in support of development (see Amalric, this issue).

In whatever camp the reader falls, CSR is an issue that needs to be taken seriously.We need to acknowledge and understand why there is this surge of interest in development practice in fostering business ethics and responsibility. Why and how has business moved into the development arena so effectively? How have states and NGOs responded to the management practices of business and in the partnerships around CSR? How does the vision of CSR feed into notions of sustainable development and the longing for a fair and stable world order for justice and security? In short, how is CSR rewriting development?

The journal explores some of these issues in articles describing the relatively short but very successful history of CSR with a number of high-profile cases in which corporations are engaged in partnerships that mark new forms of global governance aimed to secure social justice and sustainability. The issue brings together researchers and practitioners of CSR, as well as other actors looking critically at the role that large corporations are playing in Latin America, North America, Africa, Europe and South Asia. They ask questions about how CSR is operating to strengthen solidarity and social justice, while at the same time outlining the negotiations to bring business on board to protect the environment, workers' rights and conditions, and while, it is fully conceded, going about their job of making profits. 


\section{Development 47(3): Upfront}

The articles do not entirely solve the polarity of whether to welcome or resist the business world's entry into the heart of development policy and programmes. The UN Global Compact, the most discussed agreement in the journal issue, signals a loss of confidence in the State as well as a sense of achievement that business is willing to come on board. It has its critics as well as its supporters. Issues of inequity and power struggles lurk in the shadows, particularly in the case studies that raise worrying questions about whether workers' rights and conditions are really going to be protected by big business. The success stories are tem- pered by the uncertainties around whether the good works today will translate down the line to a sustained change, particularly in the vulnerable economies of the South. We can note the same uncertainties surround many development activities. And learning from that, we need to maintain a healthy scepticism that questions and 'denormalizes' business practices as we would do any other development activity. We hope the journal issue manages to do just that - to shake our tacit assumption that CSR is somehow given and therefore to look with scrutiny at the role it plays in the global governance structures we face today.

\section{Note}

1 My editorial was inspired not only by the articles published in Development 47.3 but also by the thought-provoking draft of an unpublished paper by Ewa Charkiewicz 'Global Bio-politics and Corporations as the New Subject of History', a version of which will appear in Volume 48 of Development. 